Fall 2008

\title{
Power and Piety: The Religiosity of Michel de Marillac
}

Donald A. Bailey Ph.D.

Follow this and additional works at: https://via.library.depaul.edu/vhj

\section{Recommended Citation}

Bailey, Donald A. Ph.D. (2008) "Power and Piety: The Religiosity of Michel de Marillac," Vincentian Heritage Journal: Vol. 28: Iss. 1, Article 3.

Available at: https://via.library.depaul.edu/vhj/vol28/iss1/3

This Articles is brought to you for free and open access by the Vincentian Journals and Publications at Digital Commons@DePaul. It has been accepted for inclusion in Vincentian Heritage Journal by an authorized editor of Digital Commons@DePaul. For more information, please contact digitalservices@depaul.edu. 


\title{
Power and Piety: The Religiosity of Michel de Marillac ${ }^{1}$
}

BY

Donald A. Bailey, Ph.D.

\begin{abstract}
A good devotion in great men, is to have a great and faithful feeling of the majesty of God, not serving him with exterior semblances, but sincerely, cordially, constantly, holding all the maxims of state and condition under the rules of conscience; and disposing themselves rather to hazard all than to lose God by one sole sin.... A good devotion [is] to attend public charges which you are to undergo, especially those that concern distribution of justice....
\end{abstract}

Several chapters later, Nicolas Caussin resumes this point: $\mathrm{He}$ "who sits in place of magistracy" should not be "contented with conscience alone, but... have science also, well to examine matters, and to observe the forms of right...." Between these exhortations concerning a true Christian statesman's practice of justice, Caussin's Holy Court asserts that "A Christian without prayer is a bee without sting, who will neither make honey nor wax." 2

Caussin's book of advice to statesmen and courtiers who wished to remain

\footnotetext{
Originally published in the Canadian Journal of History / Annales Canadiennes D'Histoire, Volume 42:1 (Spring-Summer 2007): pp. 2-24. Reprinted with their, and the author's, permission. All rights reserved by the $C J H$. For more information on the $C J H$, please visit their web site: www.usask.ca/history/cjh

An initial draft of this paper was presented at the $21^{\text {st }}$ Annual Conference of the Western Society for French History, on 16 October 1993, hosted by the University of Montana, Missoula. I wish to thank Professor Ann W. Ramsey, of the University of Texas at Austin, for her searching critical comments on that occasion, and my colleagues Victor Batzel and Garin Burbank, of the University of Winnipeg, for their helpful reading of early drafts. More recently, anonymous readers for scholarly journals have also been of great assistance.

Readers should be informed that a very few changes have been made for this reprinting of the article from the $\mathrm{CJH}$. Any typos that slipped through were sought for, and the subsequent publication of my edition of LaVie de Michel de Marillac (1560-1632): Garde des sceaux de France sous Louis XIII, by Nicolas Lefèvre, sieur de Lezeau (Québec, QC, Canada: Les Presses de l'Université Laval, 2007), suggested that we should move references to it from the future to the past/present tense.

I would like to dedicate this reprinting of "Power and Piety" to the late Professor Ronald S. Love (State University of West Georgia), whose sudden and premature death this past winter is a sad loss to both the profession and his many friends. It was Ron who, now many years ago, initially suggested that I write this paper.

Nicolas Caussin, S.J., The Holy Court, in three tomes. Written in French by.... Translated into English by $S^{r} T$ [homas] H[awkins]. And dedicated to the Queene of Great Britaine [sic]. The third Tome now first published in English: the first and second newly reviewed, and much augmented according to the last Edition of the Author. (N.p.: John Cousturier, 1634), 118, 178 and 135, respectively. (Spelling modernized.)

Carlos Sommervogel, S.J., Bibliothèque de la Compagnie de Jésus, Nouv. Éd. (Bruxelles/Paris: Oscar Schepens / Alphonse Picard, 1891), Tome II, suggests that this translation was based on Caussin's $11^{\text {th }}$ edition, rev. et aug. (Paris: Sebastien Chappelet, 1633) in three volumes, and that it was published in Paris.
} 
devout Christians while participating actively in the world was first published in 1624. ${ }^{3}$ In August of that year, Michel de Marillac became co-surintendant des finances in the Council of Louis XIII that Cardinal Richelieu had only re-entered in late April. Less than two years later, on 1 June 1626, Marillac began his six-anda-half-year tenure as garde des sceaux. ${ }^{4}$ In these two exalted positions, he was an outstanding exemplar of Caussin's Christian statesman. He administered both finance and justice with unequivocal conscience, was noteworthy for the "science" he brought to his posts, and performed his prayers and other devotions on a daily basis. But in the year The Holy Court appeared, Marillac was 64 years old, and all who knew him had been well aware of the devotion of his life and career for already thirty years. Although it was immediately popular and oft-revised and republished, the book certainly had a greater impact on Marillac's biographer than it did on Marillac himself.

Nicolas Lefèvre, sieur de Lezeau, ${ }^{5}$ who was to write his hagiographic biography of Marillac largely in the 1640s and '50s, was a friend of the Jesuit father Caussin. The parallels between Caussin's Holy Court and Lezeau's Histoire de la vie

Nicolas Caussin, S.J. (Troyes, 1583 - Paris, 1651), taught at Rouen, La Flèche and Paris, but won fame with The Holy Court in 1624 and its subsequent revisions and augmentations. Notably devout, he was named royal confessor in March 1637, only to be exiled to Quimper in December, because of his insistence that the war with Catholic Spain was contrary to God's will. Yet in these few months, he (and Richelieu as well) played a crucial role in winning royal clemency for Anne of Austria in the face of her treasonous correspondence with her brother, Philip IV, and in urging the king towards his conjugal duties. These duties, soon resumed, were to give France the long-desired Dauphin in September of the following year. After 1643, Caussin became confessor to the Grand Condé.

4 As this article mentions most aspects of Marillac's life and career in their thematic place, there is no need to summarize them here. But these key dates may be desirable presented together: birth in Paris, 28 August 1560; conseiller au Parlement de Paris, 3 September 1586; marriage, 12 July 1587; maitre des requètes, 24/25 January 1595; second marriage, September 1601; establishment of first reformed Carmel in France, 17 October 1604; conseiller d'État, 1612; publication of Marillac's Imitation of Christ, 1621; co-surintendant des finances, 27 August 1624; publication of his translation of the Psalms, 1625; garde des sceaux, 1 June 1626; publication of the Royal Ordonnance of 1629, January 1629; the Day of Dupes and Marillac's disgrace, 10-12 November 1630; death at Châteaudun, 7 August 1632.

5 Nicolas Lefèvre, sieur de Lezeau (1581-1680), was received in the Grand Conseil in 1602 and then became Président aux Requêtes du Palais and Maître des requêtes in 1618. He became a Conseiller d'État in 1657 and died as dean of the Councillors of State on 1 November 1680, just short of his $100^{\text {th }}$ birthday. François Aubert de La Chenaye-Desbois and Badier, Dictionnaire de la Noblesse, $3^{\text {rd }}$ ed. (Paris: Schlesinger frères, 1868). Colin Kaiser writes that Lezeau was sent to Lorraine in 1634 as an intendant to the army (433) and that he sold his office of maitre des requêtes in 1639 to Jacques Barrin for 161,000 livres (195). "The Masters of Requests: an Extraordinary Judicial Company in the Age of Centralization (1589-1648)" (Ph.D. dissertation, University of London, 1977). For more on Lezeau and his family, see Jean-François Solnon, Les Ormesson au plaisir de l'État ([Paris]: Fayard, 1992).

Lezeau wrote two other works, "Apologie pour le sieur de Marillac garde des sceaux de France contre un libelle diffamatoire publié sous le titre d'Entretiens des Champs-Elisées" (Bibliothèque nationale de France, cote Ms. fr. 17485), and "De la Religion Catholique en France" (Bibliothèque SainteGeneviève, cote ms. 583), published by M.L. Cimber and F. Danjou, in Archives curieuses de l'histoire de France depuis Louis XI jusqu'à Louis XVIII, $1^{\text {re }}$ série, tome 14e (Paris: Imprimerie de Bourgogne et Martinet, 1837), 9-91. The latter has been analyzed by Barbara Diefendorf, in an article to be found in an unfortunately obscure journal: "Reconciliation and Remembering: A Dévot Writes the History of the Holy League," Cahiers d'Histoire: La Revue du Département d'Histoire de l'Université de Montréal 16:2 (Automne 1996): 69-79. 


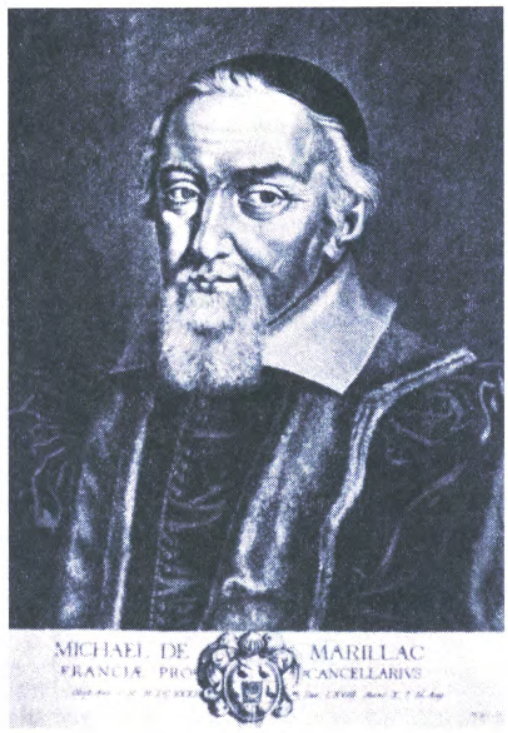

Michel de Marillac. Portrait engraving. Image Collection of the Vincentian Studies Institute

de messire Michel de Marillac chevallier garde des sceaux de France are indeed striking, despite the organizational differences imposed by the respective literary genres. It might be rash to argue that Lezeau consciously patterned his work on the earlier one, but he certainly echoed it in his chapters on Marillac's personal traits and talents, friendships, distaste for worldly wealth and pleasures, exercise of high office, efforts to blend the majesty of royal office with the humility of a Christian pilgrim, and daily life-long exercise of piety and devotion. The biography is a virtual checklist of the manual.

Lezeau's biography is familiar to all students of Marillac, but most of us have undervalued its testimony because our interests in him were political and secular, even with respect to his religious activities, while the biography's hagiographic approach and frequent religious preoccupations appeared to render its contents unreliable, irrelevant, or both. My goal is to redeem the text, for two purposes. First, it fleshes out just what Marillac's religiosity consisted of - his religious practices, spiritual experiences, personal sacrifices, and theological convictions. Second, it illustrates the point that his life and character were of a single piece; Lezeau amply illustrates the standards Marillac set for friendship, the rigor with which he followed petty and inconvenient rituals, his disdain for personal physical comforts and material possessions, his devotion to precision in both knowledge and performance, and his emphasis on higher and more distant goals.

In the opening line of the Preface to his almost 800-page manuscript, Lezeau states that he owes it to posterity to trace what he has "seen, known and learnt of the saintliness of life, the solid piety, and the rare virtues of the very illustrious garde 
des sceaux de France maître Michel de Marillac."' ${ }^{\prime \prime}$ After briefly listing the special attributes of Marillac that he intends to describe in the following pages, Lezeau says he wants Marillac to be taken as "a most perfect exemplar" by those in the future "who, in public charges or other employments of the world, would wish to pursue the spiritual life and advance to Christian perfection." ${ }^{\prime 7}$ Marillac, he writes a few pages later, "in the public functions and offices of a secular and lay life, bore and conserved devoutness to a most perfect degree, in such a way that scarcely in a century or two will one find his equal." 8 Lezeau concedes that his age knows many men and women of a singular piety and holiness who adopted the religious vocation. But among laymen of capacities similar to Marillac's, fully employed in the tasks of temporal affairs, one only rarely finds anyone who remunerated himself so little and who retained such a spirit of holiness so fully. ${ }^{9}$

How could Lezeau's Vie de Marillac not be seen as the perfect reflection of Caussin's devout courtier/statesman? Marillac, Caussin and Lezeau were all products and, indeed, illustrations of the Catholic Renaissance in France. At an intellectual, even ideological, level, the movement was driven by the proclamations of the Council of Trent and the Catholic Reformation in general; the Gallican Church officially, and both clergy and pious laity zealously, urged the formal adoption of Tridentine reforms. In France, the long period of religious wars had evoked profound feelings and expressions of piety, initially in the abandoned or bereaved wives and mothers, but eventually in their menfolk as well. ${ }^{10}$ Dramatically illustrated in the partisan violence of the war years, the religious revival was more profound and enduring in all forms of religious worship: increased church attendance, more frequent confession and communion, private prayers by laymen imitating the orisons for centuries practiced only by clergy, and even the discipline of scourging belts or short whips.

Lezeau's biography presents Marillac as active in all these practices and more, despite the exercise of high office or periods of illness. And both men were undoubtedly familiar with the Introduction à la vie dévote, written by François de Sales ${ }^{11}$ only a few years after this putative bishop of Geneva came to Paris (January-

Four and a half manuscript versions of Lezeau's Histoire de la vie de messire Michel de Marillac chevallier garde des sceaux de France are extant in Paris (with negligible variations in the title). Although for my edition of Lezeau's Vie de Marillac, I compared them all, my base text was the one at the Bibliothèque nationale de France, Département des Manuscrits, cote Ms. fr.14027. However, this version lacks the Preface, so my citation for this quotation is the version at the Bibliothèque Sainte-Geneviève, Salle des Réserves, cote 826 , fol. $10 \mathrm{v}^{\mathrm{o}}$. All translations are my own. Since all folio-pages are indicated in my edition of Lezeau's Vie de Marillac, any reference in this and subsequent notes may be easily applied to the now published version.

Lezeau, La Vie, fol. $11 \mathrm{v}^{\circ}$.

Ibid., fol. 13.

Loc. cit.

10 These remarks summarize points made in Lucien Febvre, "Aspects méconnus d'un renouveau religieux en France entre 1590 et 1620," Annales: Économies, Sociétés, Civilisations, 13e année, n 4 (oct.déc. 1958): 639-50.

11 François de Sales (château de Sales, Thorens, Savoy 1567 - Lyon 1622; canonized 1666), a docteur de l'église, was ordained in 1593 and elevated in 1602 to bishop of Geneva (effectively, of Annecy, since the 
September 1602) and advised Mme. Acarie's circle concerning the introduction of the reformed Carmelite Order to France. Although not explicitly addressed to courtiers and statesmen, as Caussin's Holy Court was to be, François de Sales's Vie dévote was much more generous with advice to help the layperson enter God's presence with prayer, avoid all cardinal sins and resist harder-to-recognize venial ones, and partake in the pleasures of secular life, including marriage, without being obsessed by their charms. ${ }^{12}$

Through their respective lives, writings and activities, both François de Sales and Michel de Marillac significantly shaped the dévot movement in France. However, Marillac better illustrates how the fanaticism of the Holy League in the late 1580s quickly evolved into the less frenzied, but still partisan worship and service of dévot Catholics in the early seventeenth century, and how their never fully repressed sympathies for the Spanish leadership of the Europe-wide CounterReformation cut short the active dévot participation in political and administrative reform of royal government in France. Yet (oddly and unfortunately) Lezeau's biography only once mentions the Genevan saint (his Paris visit in 1602) and provides very little detail concerning the "dévot party" in the Court and Council, let alone the cleavage developing between Richelieu and Marillac that led to the latter's disgrace on 12 November 1630.

Nonetheless, as is well known, Lezeau's extensive Vie de Marillac is a rich source of information concerning Marillac's family, life, career in royal service, contributions to religious reform, and personal devotions. ${ }^{13}$ Even as a layman, Marillac was hardly the only, perhaps not even the best, model of the devout Christian envisaged by François de Sales and Nicolas Caussin, but he did attain higher royal office than any other dévot and so is worthy of the special attention given him by his old friend. ${ }^{14}$

Catholic "bishop of Geneva" had long been in exile from that Calvinist-controlled city). Inspired by the spirituality of Saint Teresa of Avila, he not only supported the Parisian efforts to introduce her reform to France, but also assisted Jeanne de Chantal in the founding of the Order of the Visitation (1612). In addition to Introduction à la vie dévote (1609, reprinted 1610), he wrote Traité de l'amour de Dieu (1616) and several other works.

12 Because he had also republished Marillac's translation of the Imitation of Christ just the year before, I read the "new" edition, reviewed and corrected by M. Silvestre de Sacy: François de Sales, Introduction à la Vie dévote (Paris: Techener, 1855), 2 vols. But myriad more recent editions abound and are available in most good libraries.

13 Lezeau and Marillac were both employed in royal administration in the opening years of the seventeenth century. Through their shared rectitude and spirituality, they formed a bond of friendship and respect that drew Lezeau ever further into the intimacy of Marillac's family and affairs and that survived the senior man's death. I know of no occasion when they worked together in the same office, even before Marillac resigned as a maitre des requêtes around 1612 to become a conseiller du roi. But in their personal lives, Lezeau virtually replaced, in the elder man's affection and trust, the son Marillac prematurely lost in 1621. In addition, Lezeau did not rely only on his own memories, but corresponded with a wide circle of political and, especially, religious associates of Marillac's, who sent lengthy replies to his enquiries and many of whom seem to have read the biography in middle to later stages of its drafting.

14 While it is true that both Louis XIII and Cardinal Richelieu were no less "dévot" than Marillac, the sharpness of the divide between the latter and the other two, occasioned by the decision for war, forces 
The nephew of two bishops, a Dominican nun, and an abbot-become-Calvinist, and the distant collateral descendant of two popes, Marillac could be expected to have at least conventional church loyalties. ${ }^{15}$ But he was orphaned young and so reared by his step-mother and one of his late father's brothers; whether from this circumstance or a natural disposition, he became a studious and devout young man. ${ }^{16}$ Although none of his siblings followed their ancestors' and descendants' pattern of hiving off one or more individuals into the religious life, young Michel did twice run away from home to pursue religious aspirations, and had to be intercepted by his tutor at the edge of town. ${ }^{17}$

upon historians a less than satisfactory distinction in terminology. Despite the resulting disservice to the many bons-Français dévots, it is Marillac's party - the bons-Catholiques dévots - that is conventionally meant when the term is used in a political context.

In the same vein, important points are lost when the dévots are interchangeably seen as "Marillac's party" or "Marie de Médicis's party." Both Marillac and the Queen Mother were devout Catholics and sympathetic to Spain, they were essentially disgraced together, and "members" of the party (irrespective of who was considered its head) were virtually identical. But the perspective or focus matters. On the one hand, there was a superstitious aspect to Marie, Louis, Richelieu, and perhaps even Bérulle's piety that is lacking in Marillac's, and on the other hand, Louis, Richelieu and Marillac's reforming ambitions - in so far as they had shape and substance at all ${ }^{*}$ - were largely similar, except that Marillac refused to sacrifice them to the war.

"See Robin Briggs's fine article, "Richelieu and Reform: Rhetoric and Political Reality," in Richelieu and his Age, eds. Joseph Bergin and Laurence Brockliss (Oxford: Clarendon Press, 1992), 71-97.

15 His most prominent uncle, Charles de Marillac (ca. 1510-1560), had pursued a career divided between his secular service to Francis I (and later Henry II, then Francis II) in the royal government and lay judiciary, and his religious service as the bishop of Vannes (Brittany), and then as archbishop of Vienne (Dauphiné). Another uncle (Bertrand, a Franciscan, d.1573) had become bishop of Rennes. A third uncle, Pierre de Marillac, had been abbé of Pontigny, before becoming, at age 40, a Calvinist and retiring to Geneva, where he married. De La Chenaye-Desbois and Badier, Dictionnaire de la Noblesse.

16 "The young Michel therefore turned immediately and with ardor towards piety and study, to which he brought a naturally serious and mystical character." Éduard Everat, Michel de Marillac, sa vie, ses oeuvres: Étude historique, juridique et littéraire (Riom: Ulysse Jouvet, 1894), 5. In this respect, Everat overlooks Marillac's step-mother, Geneviève de Boislévesque. Marillac's life-long concerns for his halfsiblings, Valence and Louis, and for Valence's virtually orphaned children, may have partial origins in the three children's having been reared by her under one roof.

17 However, one of Michel's sons became a Capuchin and was later nominated to the bishopric of Saint-Mâlo, while Michel's daughter, daughter-in-law, three granddaughters and a great-granddaughter all became Carmelites. One of his grandsons entered the law and another the church, and this division was replicated in the next two generations as well. Also, in 1604, Michel had become guardian for his eldest brother's natural daughter, Louise de Marillac (1591-1660), monitored her education, advised on her marriage to Antoine Le Gras de Montferrand in 1613, and no doubt approved her falling under the influence of Vincent de Paul. Widowed in 1625, Louise helped Saint Vincent found the Filles de la Charite in the 1630s, of which she was the first mother superior; she also worked closely with the Dames de la Charité. Like Vincent (in 1737), she was eventually canonized (in 1934). Cf. Barbara B. Diefendorf, From Penitence to Charity: Pious Women and the Catholic Reformation in Paris (New York: Oxford University Press, 2004).

For further and ampler details on Marillac's extended family, please consult Appendix 2 in my edition of Lezeau's Vie de Marillac, or alternatively, Donald A. Bailey, "The Family and Early Career of Michel de Marillac (1560-1632)," in Society and Institutions in Early Modern France, ed. Mack P. Holt (Athens: The University of Georgia Press, 1991), 173-75. The reference to his uncle Bertrand, the bishop of Rennes, is from Lezeau directly (fol. $\left.45 \mathrm{v}^{\circ}\right)$.

It might also be noted that his great-grandson, Louis de Marillac (d. 25 February 1696), was a docteur de Sorbonne, in 1670 curé of Saint-Germain-l'Auxerrois, and in 1696 curé of Saint-Jacques-laBoucherie, as well as being Prior of Langeay (or Langeais). A formal portrait of this descendant may be 
Signs of a stronger religiosity emerged during his period as a conseiller au Parlement. He was one of the hotheads who, on 16 January 1589, burst into the Parlement with Jean Leclerc, dit Bussy-Leclerc (d. 1635), to arrest a handful of magistrates thought to be soft in their sympathies to the Holy League. Ten days later, Marillac took the oath (serment) of the Catholic Union. He may have been a Grey Penitent by $1590,{ }^{18}$ and in 1594, he was elected churchwarden in his parish of Saint-Gervais. Marillac's preference for civil order, however, and Henri IV's increasing demonstration of willingness to convert brought the two into cooperation. Marillac was made a maître des requêtes in 1595 and served the king in that important capacity until the latter's assassination and beyond. In mid-1602, however, Marillac joined Mme. Acarie's pious circle and immediately threw himself zealously into the establishment of the reformed Carmelites in France. For the rest of his life, royal service and religious service shared his energies and commitments, and did so in both complementary and competing ways.

Well before his entry into high office, Marillac attended all matins in his parish on feast days and Sundays. ${ }^{19}$ He practiced the austerities and spiritual mortifications of the Catholic Reformation in France: sleeping on the tile floor of his hotel's chapel, refusing a feather bed when deteriorating health forced him off the tiles, remaining up late into the night, frequent fasting, etc. He even wore "a belt of small silver bow knots" - that is, a sharply studded girdle around his waist, from which many zealous penitents occasionally sustained bloody wounds. And he often used the "discipline" - a short whip of cords or small chains with which extremely devout persons flagellated themselves. ${ }^{20}$

The religious work for which he became renowned began when Marillac and the devout Pierre de Bérulle helped Mme. Acarie establish the first house of St. Teresa's reformed Spanish Carmelites in France. Eventually widowed, Mme. Acarie was to join the order herself in 1615, taking the name of Marie de l'Incarnation. $^{21}$ In November 1611, Marillac and his second wife, Marie de Saint-

found in the Département des Étamps, BnF (site Richelieu), cote D206919, and as Figure 17 (p. 468) in my edition of Lezeau's Vie de Marillac.

18 The only source to suggest this is Arlette Jouanna et al., Histoire et Dictionnaire des Guerres de Religion (Paris: Robert Laffont/Bouquins, 1998). "Marillac," 1083. Larousse's Grand Dictionnaire universel du XIX siècle describes penitents as members of "certain lay confraternities in which one made characteristic exercises of penitence"; the color of their robes identified them; they carried, at least in processions, scourges or whips at their belts and rosaries of ivory beads sculpted into skulls. This dictionary states that the pénitents bleus of Languedoc and Dauphiné actively participated in the civil wars of the Ligue (vol. XII, "Pénitent, -ente," 552/3).

19 Lezeau, La vie, fols. $126 \mathrm{v}^{\mathrm{o}}-126^{\text {bis. }}$.

20 Lezeau, La vie, fol. 152-53 ("une ceinture de petites rosettes d'argent"). This asceticism was common to both the men and women in Mme. Acarie's devout circle (Diefendorf, From Penitence, 91), but remember that Marillac was one of the few male lay members of the group who remained a layman all his life. Marie Deslandes [Mme. de Lamoignon, 1576-1651], an early member of the Dames de la Charité, once fainted during her charitable rounds amongst the poor from the wounds inflicted by the spiked iron bands under her hair shirt. Diefendorf, From Penitence, 239 \& 257.

${ }_{21}$ Barbe Avrillot (1556-1618) had an idyllic, partly pastoral childhood, reinforced by education with the Clares at Longchamp. In 1582 she married Pierre Acarie, a maitre des comptes, the shared piety of the two families being part of the mutual attraction. The Acaries' heavy commitment to the League 
Germain, along with Mme. Acarie and other pious persons, took communion together on the occasion of the founding of the first house in France of Bérulle's long-sought Oratory of Jesus and Mary. ${ }^{22}$ On the eve of Bérulle's death in 1629, the two friends were working to bring to fruition an earlier ambition of Vincent de Paul and François de Sales's, namely the lay order known as the Company of the Holy Sacrament. ${ }^{23}$

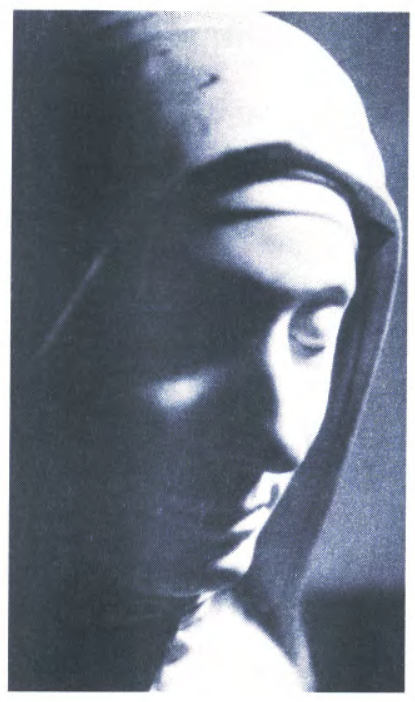

Madame Acarie. Public Domain

Marillac diverted a considerable amount of time from his busy career to the giving of advice, legal assistance, financial sustenance, and prayerful reverence to the Carmelites and other religious orders. In addition, he translated into French prose Thomas à Kempis's Imitation of Christ (which saw four editions between 1621 and Marillac's death in 1632 - and more editions subsequently) and, into French verse, the Psalms. Under house arrest at Châteaudun in the last two years of his life, he wrote a "Story of Job" and a "Treatise on Eternal Life." Throughout

almost ruined them financially, and Mme. Acarie had to retire for a time to a modest property she had been able to save at Bercy. Georges de Cadoudal, Madame Acarie. Étude sur la société religieuse aux XVI' et XVII siècles (Paris: Ve Poussielgue-Rusand, 1863), 35-37, 41, 101-05, 130. The Acaries worshipped in the church of Saint-Gervais (56), the same church as Marillac's.

22 Charles E. Williams, The French Oratorians and Absolutism, 1611-1641 (New York: Peter Lang, 1989), 88. The Oratory was inspired by Saint Charles Borromeo's Oblates of Saint Ambrose, founded in Milan in 1578, and by Saint Philip Neri's earlier Congregation of the Oratory, founded in Rome in 1564.

I have encountered not a single reference concerning the religious attitudes or activities of Marillac's first wife, Nicole Barbe de La Forterie (1561-1600).

23 Bailey, "Family and Early Career," 174, 176-77. In his dissertation on the Company, Emanuel Chill traces its founders' desires back almost a decade before its actual foundation in 1629. "The Company of the Holy Sacrament, 1630-1666; Social Aspects of the French Counter Reformation" (Ph.D. dissertation, Columbia University, 1960). 
his life Marillac received communion several times a week, in an age still hesitant to follow the Tridentine exhortation to take communion at no fewer than monthly intervals. Lezeau writes that in the years Marillac was in his two great offices, he failed to hear mass daily on only six occasions, even including when he was ill. ${ }^{24}$ He consecrated many hours each week to prayer, devotional reading, acts of religious service, and pious conversations with Mme. Acarie until she took the veil, after which they frequently exchanged letters. ${ }^{25}$

I think it is manifestly evident that it was the religious edge to Marillac's political attitudes that made him, if one may put it this way, more of an absolutist, that is, less of a pragmatist, than Cardinal Richelieu. Marillac's experiences as a maitre des requêtes sent on mission to the provinces in the $1590 \mathrm{~s}^{26}$ his tidy legal mind and passion for order, and his loyalty to the monarchy are all secular and necessary explanations for the inclination towards centralized royal power that also led many of his contemporaries to build absolutist monarchy. ${ }^{27}$ But are these reasons sufficient to understand Marillac? I suggest that it is Marillac's inflexibility, about royal authority and about the war of 1629 , that requires further explanation. ${ }^{28}$ As Emanuel Chill writes (in passing), “Marillac's political dissidence was inspired

$24 \quad$ Lezeau, La vie, fols. $125 \mathrm{v}^{\mathrm{o}}-126$.

25 Bailey, "Family and Early Career," 176-77. Lezeau writes that between 1602 and 1614 hardly a day went by that Marillac and Mme. Acarie did not spend more than one and a half hours together (fols. $\left.26-26 \mathrm{v}^{\circ}\right)$. When she took the veil, she resolved to write or receive no correspondence with friends in the world, and she made Marillac the only exception to this rule. She thought his letters so edifying that she shared them around the convent, but on her deathbed, she ordered her sister nuns to see that they were all burned (fols. 37-37 $\mathrm{v}^{\circ}$ ). Lezeau himself apparently saw Mme. Acarie "two or three times" around 1610. P. Bruno de Jésus Marie, La Belle Acarie: Bienheureuse Marie de l'Incarnation (N.p.: Desclee de Brouwer, 1942), xx.

26 For the impact of his experience in the provinces on Marillac's attitudes, see J. Russell Major, "Henry IV and Guyenne; A Study Concerning the Origins of Royal Absolutism" in French Historical Studies 4:4 (Autumn 1966): 368-83; reprinted in idem. The Monarchy, the Estates and the Aristocracy in Renaissance France (London: Variorum Reprints, 1988), 363-83.

27 In the chapter (XIII) on Marillac's intelligence and capabilities, Lezeau asserts that his mentor was one of the few maitres des requêtes who actually knew the ordonnances and customs of the hôtel $d u r o i$, and that Chancellor Sillery was quick to appreciate this. Lezeau continues, Marillac always carried a notebook in which he had itemized the points of the law $\left(\right.$ fol. $\left.172 \mathrm{v}^{\circ}\right)$. As garde des sceaux he often drafted the king's edicts and other letters himself, because he knew they would then be done properly (fol. 174). He always carried pencil and paper with him so that he could note down things done, observed or to be looked into $\left(\right.$ fol. $\left.174 \mathrm{v}^{\circ}\right)$. Upon entering finances, and later the chancery, Marillac drew from colleagues expressions of astonishment at how much he already knew (fols. 177-177 $\mathrm{v}^{\circ}$ ). Again, the marks of hagiography are everywhere apparent, but it should be noted that the various copies of a 210-folio-page manuscript often entitled Traité inédit "du Conseil du Roi" (consultable at the $\mathrm{BnF}$, the Bibliothèque Mazarine, \& the Archives nationales) usually have their authorship attributed to Marillac.

28 In his letters to Richelieu in 1629-30, Marillac reveals his awareness of Spanish self-interest and of the reasons for defending the Nevers-Gonzaga claims to Mantua, but every such statement is qualified by reminders to finish the work so well begun within France itself, and to avoid going beyond the absolutely essential goals of the war. Pierre Grillon, ed., Les Papiers de Richelieu. Section politique intérieure: Correspondance et papiers d'état, Tomes I-VI [1624-1630] (Paris: A. Pedone, 1975-1985). Tome V (1630), e.g., \#66 (from Paris, 12 February), 77; \#224 (Dijon, 26 April), 234; \#377 (Grenoble, 7 July), 373; and \#410 (Grenoble, 17 July), 406. Reading between the lines, it is clear that he sees the cardinal as carrying the military advances too far. 
purely by his religious zeal...."29

While it is true that rigid personalities easily take shape without benefit of religion, I think Marillac's rigidity owed much to his religious fervor and selfrighteousness. He was ever ready to judge his fellow men, and religious and political judgements easily commingled in his mind; religious righteousness became political rectitude, and he believed that both royal authority and divine judgement should be invoked to ensure that laws were enforced, taxes paid, corruption or lassitude reined in, and the king's will respected throughout France. Reinforcing the point from a different perspective, Richard Bonney observes:

When Michel de Marillac made a speech on "le bon ordre de gouverner," he talked of bishops, curés, the ecclesiastical and seigneurial courts, the Parlements, the nobility, the provincial governors, the towns and the Protestants. Marillac's well-ordered polity contained social, political-religious and administrative groups, and these were undifferentiated. ${ }^{30}$

Turning first to Lezeau's discussion of his use of political office, on the larger issues Lezeau felt circumscribed, as he himself stated as delicately as he could, by the tensions in the royal council during the "year of tribulations" that led to Marillac's dismissal and by the continuing power of Cardinal Richelieu. Thus, Lezeau can devote an entire, albeit brief, chapter to the siege of La Rochelle (XI), where Marillac and Richelieu had worked in close collaboration, ${ }^{31}$ but he utters not a word about the War of the Mantuan Succession, during and by means of which the two men's policy differences reached a crisis. However, he also devotes a chapter (III) to reproducing Marillac's own deceptively narrow sketch of his activities as a Ligueur in the 1580 s and '90s, an account focusing on his role in

29 Chill, "The Company of the Holy Sacrament," 58.

Some ink has been spilt in recent decades over the question of whether Marillac or Richelieu was the greater "absolutist." Major writes, "Marillac was... much more authoritarian and inflexible than Richelieu": Representative Government in Early Modern France (New Haven, CT: Yale University Press, 1980), 492. Richard Bonney, however, does not share that judgement: King's Debts: Finance and Politics in France, 1589-1661 (Oxford: Clarendon Press, 1981), 145, note 2. Previously, I have put myself unequivocally in the Major camp, but my view now is that an important distinction in historiographical perspective is usually overlooked in this debate: One can imagine an "absolutist" reform program, vision, goals - that is, to be an ideological absolutist, rigid and authoritarian in attitude and ambition - such as Marillac. Or one can be content to leave most things as they are, yet be determined to have the royal will quickly obeyed on every occasion that unquestioning obedience appears necessary - as during the exigencies of open war, but even occasionally in "normal" times - which I think better captures the spirits of Richelieu and his king. Since the latter two had more exigencies over more years requiring the imposition of their will, naturally they will seem more "absolutist" than Marillac, upon whose greater "ideological absolutism" I still insist.

30 Richard Bonney, "The Intendants of Richelieu and Mazarin, 1624-1661" (D.Phil. dissertation, Oxford University, 1973), 20. I cannot locate this passage in Bonney's subsequent book, Political Change in France under Richelieu and Mazarin, 1624-1661 (Oxford: Oxford University Press, 1978), nor in The King's Debts.

31 Lezeau, La vie, cap. 11, fols. 146-151. 


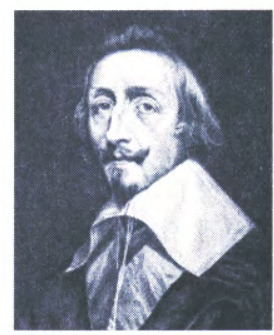

Cardinal Richelieu. Engraving. Public Domain

the Parlement's decision to recognize Henry of Navarre. ${ }^{32}$ A fuller account would show that Marillac favored a Lorraine prince's election to the throne as late as early 1594, and was forced in 1595 to sell his office in the Parlement of Paris under pressure from the loyalist magistrates. ${ }^{33}$

Lezeau can also look at the manner in which Marillac executed his responsibilities as surintendant des finances and then as the effective minister of justice. He describes Marillac's attempts to stiffen procedures, reduce the size of administrative personnel, and curb lax or improper behavior. ${ }^{34}$ We are told that Marillac was the only maître des requêtes willing to handle a peasant's case against a fellow maitre. ${ }^{35}$ And Lezeau mentions several instances where Marillac denied efforts by colleagues to obtain favors for friends or relatives at the expense, as he saw it, of the king. ${ }^{36}$ In his brief chapter on the Ordonnance of 1629 (XV), Lezeau

32 This account was thrice published in the early nineteenth century. First, Claude-Bernard Petitot, ed., Collection complète des mémoires relatifs à l'histoire de France, vol. XLIX (Paris: Foucault, 1826), 441-479, the actual "Mémoire de Michel de Marillac de la Ligue," starting at p. 453. The only significant difference between Lezeau and Petitot is in the description of the second of Marillac's three "signal actions" in the court. The other two reprintings were in Pierre Victor Palma Cayet's Choix de chroniques et mémoires, vol. 2 (Paris, 1836), 517-30, and Joseph François Michaud and Jean Joseph François Poujoulat's Nouvelle Collection des mémoires, vol. XI (Paris, 1838), 535-48. Each of these is prefaced by the same letter from Marillac to Bérulle (undated) and by different brief biographies of Marillac; none other than negligible textual differences obtain among these three publications. Lezeau presents Marillac's letter to Bérulle much later in his biography, at the very end of Chapter XIV (fols. $\left.215 \mathrm{v}^{0}-222 \mathrm{v}^{\circ}\right)$. (Lezeau suggests the dates 1627-28.)

By the way, few scholars share Marillac's claim about the importance of his own role, though the challenges of interpretation are complex.

33 Chill writes, "Principle rather than profit apparently determined Marillac to abandon the Holy League. He had observed at first hand the actual anarchy of revolutionary government...; his feeling for order and discipline asserted itself...": "The Company of the Holy Sacrament," 56. Chill relies on Léon Desjonquères, Le garde des sceaux Michel de Marillac et son oeuvre législative (Paris, 1908), 44. The governor of Paris, François d' $\mathrm{O}$, followed the king's orders not to conduct a purge (Desjonquères, 51).

34 Lezeau, La vie, fols. $192 \mathrm{v}^{\circ}-193,218 \mathrm{v}^{\circ}-219$, and $220-221$; and then fols. 196-198v $\mathrm{v}^{\circ}, 219-219 \mathrm{v}^{\circ}$, and $221 \mathrm{v}^{\mathrm{o}}$-222. Although most biographers note Marillac's integrity and high intentions as surintendant, Richard Bonney sees little improvement in the actual expenditures during Marillac's tenure. In any case, he notes, "Richelieu exercised a determining influence on financial policy..." Bonney, The King's Debts, 116-17, including note 4 .

35 Lezeau, La vie, fol. $186 \mathrm{v}^{\circ}$.

36 For his refusal of requests from fellow maitres, see Lezeau, La vie, fols. $204 \mathrm{v}^{\circ}-205 \mathrm{v}^{\circ}$. He refused to help the brother of his first wife advance from a provincial financial office to that of trésorier de France $\left(\right.$ fols. $\left.189-189 \mathrm{v}^{\circ}\right)$. He forbade his immediate subordinates to benefit from their employ (fols. $188 \mathrm{v}^{\circ}$ and 
focuses exclusively on a defence of article 99 , which had sought to restrict some of the activities of the parlements and to which his former colleagues vigorously objected. ${ }^{37}$

One striking example brings several of these themes into focus: Pomponne de Bellièvre, son of Nicolas de Bellièvre (1585-1650) and of the acceptable age of twenty-one, had sought to become a conseiller in the chambre des requêtes of the Paris Parlement, in which his father had been a président à mortier since 1614. As garde des sceaux, Marillac opposed this request, since the previous three law codes (Orléans, 1560; Moulins, 1566; and Blois, 1579), proclaimed by Charles IX and Henry III, had forbidden such close relatives to enjoy positions simultaneously in the same court. Furthermore, the rule was consistent with Marillac's overall vision for reform of the parlements. In January 1629, Louis XIII overturned the rule as it applied to fathers and sons, and Pomponne de Bellièvre entered the Parlement. ${ }^{38}$ Now, Marillac not only owed much of his middle career to the young man's grandfather of the same name (chancellor, 1599-1607) but venerated enormously the grandfather's probity and integrity, partly on account of which Marillac and Nicolas de Bellièvre enjoyed considerable mutual respect. In opposing the grandson's entry into the Parlement, Marillac was blocking the family's ambitions, and yet one could equally say that Marillac was honoring the grandfather's memory, and authenticating Lezeau's personal judgement about his colleague.

A reading of Marillac's letters to Richelieu qualifies Lezeau's judgement only slightly. When Marillac's half-brother, the marshal Louis de Marillac (1573-1632) was suddenly struck with a life-threatening pleurisy, at the end of May 1630, the garde des sceaux importuned Richelieu to have the king remember Louis's wife and his deceased sister's children by providing them with an honorable subsistence. ${ }^{39}$ Louis de Marillac's wife, Catherine de Médicis, was in fact a distant cousin of the queen mother's - but was not as distant as Marie de Médicis from the extended family's most recent pope, Leo XI (Alexander-Octavian de Medici, reigned only 1-27 April 1605). Louis's sister, Valence de Marillac, and her husband, Octavien Doni, sieur d'Attichy, had both died by 1617, after giving birth to an indeterminate number of children, on whose names genealogists also disagree. ${ }^{40}$ Four of their

190-190vº). To his daughter-in-law he once said, "If I should not do it for another, I should not do it for you" (fol. 191). Having refused a favor to the Queen Mother, he said he could equally deny them to the great (fol. 193). However, he had to seal letters to the benefit of Richelieu on the express orders of the king $\left(\right.$ fol. $\left.198 \mathrm{v}^{\circ}\right)$. See also fols. $237 \mathrm{v}^{\circ}-238$.

The Introducteur des ambassadeurs, René de Thou, sgr. de Bonneuil, wrote Richelieu in 1626 to complain that Marillac had refused to proceed with certain letters of State from the king that Richelieu had obtained for him, "saying that he had taken an oath not to cede them." The concern seemed to be that Bonneuil would have to default on some debts. Grillon, Tome I (1624-1626), \#175 (from Paris, 17 August), 436.

37 Lezeau, La vie, cap. 15, fols. 223-230. He writes that in less than six months, 20,000 volumes of the 461-article Code were sold in Paris alone (fol. 226).

38 Grillon, $I V(1629), 17$, note 11.

39 Grillon, $V$ (1630), \#278 (from Lyon, 30 May), 286. Valence de Marillac was Michel's half, but Louis's full, sister; hence my use of the singular for the possessive pronoun.

40 As mentioned in note 17, for ampler details on the family's genealogy, see Appendix 2 in my 
perhaps half-dozen children were, at the time of Louis's pleurisy, in their twenties and already embarked upon careers. One, Louis Doni d'Attichy (1598-1664), had, or was just about to, become the bishop of Riez. ${ }^{41}$ It is thus hard to know just how much support this part of the family might genuinely need - or what the garde des sceaux might have expected for their sustenance.

Perhaps more questionably, Marillac was so anxious for his younger son, Octavien (the capuchin père Michel), to be promoted to the bishopric of Saint-Malo that he several times requested Richelieu to support this favor even before the incumbent bishop had died (though each time, Marillac had been, incorrectly, so informed). When the opportunity was at last real, Marillac wrote the king and queen mother as well, a prudential zeal given that the gift was formally in the hands of Marie de Médicis. ${ }^{42}$ This recommendation proceeded to the Vatican, but whether, as Lezeau claims, père Michel refused the honor, ${ }^{43}$ or he simply died (29 July 1631, about half a year after Marillac's disgrace) before the bulls were sent, Marillac failed to see the fruit of his exertions. Marillac had also recommended his brother to Richelieu's attention for various services involving negotiations about Verdun, and most notably urged Richelieu to award Louis de Marillac a marshal's baton (which he eventually received on 3 June 1629). ${ }^{44}$

Because of the contemporary concept of pietas, no scholar would normally be critical of Marillac's interventions in these cases. ${ }^{45}$ Attempting to provide for one's family was considered a social, even a moral obligation, but Lezeau's always laudatory claims inevitably provoke such questions. When one is eulogized to

edition of Lezeau's Vie de Marillac. It seems unnecessary to burden the present article with all the details and citations.

${ }^{41}$ Marillac wrote especially to recommend the bishop of Riez to Richelieu's attention on 24 July 1630 (from Grenoble), Grillon, V (1630), \#435, 432. Louis Doni's appointment to the bishopric had been at least as early as October 1628, but the authorizing bulls and formal installation were somewhat later. He was later translated to the bishopric of Autun. See Blet, Le Clergé de France et la Monarchie (1615-1666) (Rome: Presse de l’Université Grégorienne, 1959), passim.

42 See Grillon, IV (1629), \#514 (from Paris, 13 August), 339-40, and \#679 (n.p., 23 November), 681-82; and $V$ (1630), \#383 (Grenoble, 9 July), 378-79, and see note 2; \#397, 403 and 407 (all Grenoble, 13 July, 15 August and 16 August, respectively), 392, 397-98, 401.

43 The last several pages of Lezeau's eighth chapter ("De sa dependence et confiance en Dieu") largely comprise statements and letters about why Marillac wanted his son to be elevated to the bishopric, and both his son's and the latter's superior's hesitation for him to do so (fols. 110-118). Octavien's (undated) letter resigning the offer is also quoted, apparently in full (fols. 117-117 ${ }^{\mathrm{vo}}$ ).

The intellectual and mental competence of père Michel was sometimes called into question, especially for so important a post. But Henri de Gondi, bishop of Paris and recently Cardinal de Retz, who ordained him, thought père Michel "would be a very good priest, and one of the great luminaries to appear in this time." Père Michel served all over the Parisian diocese and humbled himself by teaching catechism in the villages, thatched cottages and caves, among herdsmen and shepherds. A justification for his nomination to a bishopric was also his reputation as a preacher and as a controversalist against heretics. But it was Marie de Médicis's desire to do a favor for the garde des sceaux that initiated the nomination. Le P. Raoul de Sceaux, Histoire des Frères mineurs capucins de la province de Paris (1601-1660) (Blois: Éditions Notre-Dame de la Trinité, 1965), II, 90.

44 See Grillon, IV (1629), \#169 (from Valence, 1 April), 189, and \#291 (Valence, 20 May), 317.

45 Referring to the writings of Wolfgang Reinhard, one of this article's anonymous readers drew my attention to this aspect of contemporary pietas. 
saintly proportions, what ordinary human actions can an alert scholar let pass? When one works alongside the extraordinarily acquisitive Cardinal de Richelieu, how much less acquisitive must one be not to be judged rapacious oneself, and to be seen as honest and virtuous, at least within universal standards? It would be severe to say that Marillac abused his position in writing to Richelieu about the marshal's wife, nieces and nephews, or for his half-brother's and son's promotions - that is, that he was making extravagant requests. ${ }^{46}$ Whatever we think about Marillac's otherwise unremarkable pursuit of favors, at worst they remind us that devout religious convictions rarely have more than a limited effect on an individual's self-aware criticism of values widely embraced in his or her own day.

Combining the more personal with the more religious side of this professional aspect of Marillac's life, we should note Lezeau's claim that in the six or seven years that he was in high office, Marillac worked from 5:00 A.M. to 10:00 P.M., and often at night in his bed, and that he never took an hour-and-a-half in recreation. ${ }^{47} \mathrm{~A}$ revealing anecdote concerns Richelieu's remark to Marillac that it had been a long time since the portraits of so many saints had hung in the rooms of a surintendant ${ }^{48}$ As surintendant, writes Lezeau, Marillac proposed that all tax farmers and traitants should be required to donate towards the alms distributed by the royal council. ${ }^{49}$

An illuminating description of Marillac's favors for the Carmelites also belongs in the category of his public life. He amply fulfilled Mme. Acarie's charge to him when, at the official opening, she said to Bérulle, "You will be the spiritual foundation of this enterprise," and to Marillac, "You, the temporal." ${ }^{50}$ It wasn't just that Marillac would devote much time to scouting sites for new religious foundations and for finding or personally risking the monies needed for their purchase, renovation and sustenance. ${ }^{51}$ He also played a major role in drafting their charters and acts of incorporation. He then saw these through the legal procedures of the royal administration and did everything he could to ensure that they received prompt and favorable approval at the Vatican. He occasionally took up residence at construction sites to supervise the work crews personally. The Carmel at Pontoise, the second to be founded (in 1605) and today the oldest in

\footnotetext{
46 While it could be argued that Louis de Marillac's military career, long and active though it was, did not quite justify his being made a maréchal de France, he had in fact been closely tied to Richelieu's fortunes and could well have sought the promotion on his own merits and connections.

47 Lezeau, La vie, fol. 60.

48 Ibid., fol. $129 \mathrm{v}^{\circ}$.

$49 \quad$ Ibid., fol. 59.

50 Cited almost everywhere, but see, for example, Cadoudal, Madame Acarie, 159-60. The convent was just off the rue Saint-Jacques, at 67 rue d'Enfer, where the Brasserie du Luxembourg is today (160-61). For a good discussion of how Bérulle fulfilled Mme. Acarie's exhortation to him, see Stéphane-Marie Morgain, Pierre de Bérulle et les Carmélites de France. La querelle du gouvernement 1583-1629 (Paris: Édition du CERF, 1995). Despite his significant spiritual leadership, Bérulle almost shattered the French Carmelites by trying to impose a special, fourth oath to the Virgin on them, but Marillac, Acarie and $\mathrm{Du}$ Val prevailed against him and peace was restored.

51 Lezeau states that Marillac gave 40,000 livres towards the building of one monastery, 16,000 livres to another, 6,000 to a third, and 3,000 to each of two more. After his disgrace, he gave 4,800 livres to the Oratorians (fols. $53-53 \mathrm{v}^{\circ}$ ).
} 
France, regards Marillac as the "père du couvent."52 Over the period 1618-1626, he found himself frequently defending the Carmelites against efforts of the Pères Carmes Deschaussés to control the nuns' affairs. ${ }^{53}$ He was similarly active in efforts to have the former Mme. Acarie (Marie de l'Incarnation) canonized after her death. ${ }^{54}$ And he apparently accepted or sought financial gifts for the order from the king and queen mother that he would not seek for himself, an example of which redirection we shall relate shortly.

One is not surprised, either historically or historiographically, to learn that Marillac was a welcome visitor at convents. They were grateful for his gifts of linen and vessels for their altars, they sought out his spiritual advice whenever possible (though the first prioress at Pontoise began to feel a little oppressed by Marillac's and Acarie's continual interventions), and at least a few nuns owed their presence there to his provision of their entrance doweries. ${ }^{55}$ At his death, his body was claimed by one convent and his vital organs by another. ${ }^{56}$ Lezeau is not alone in telling us that the transportation of both attracted devotions along the route and especially at stopping places.

While the ties are depicted as strong between Marillac, on the one hand, and Mme. Acarie, Pierre de Bérulle, other religious persons and Lezeau, ${ }^{57}$ on the other, Lezeau opens a chapter (XVI) entitled "De ses amis" with the startling statement that Marillac had no friends. He immediately qualifies this by mentioning the few persons with whom Marillac was close, but emphasizes that Marillac sought and, indeed, enjoyed very few secular friendships, either with colleagues in the king's service or in the convivial society of his neighbors and peers. ${ }^{58}$ He found most social intercourse superficial and most of his contemporaries lacking in gravity and devotion. Lezeau wrote that Marillac, not wanting to gossip or spend idle

\footnotetext{
52 See my presentation "Michel de Marillac et le Carmel de Pontoise" to the colloquy (19-20 November 2004) celebrating the $400^{\text {th }}$ anniversary of this convent's founding. Its principal organizer, Christian Renoux, expects to publish the proceedings.

53 Chapter $\mathrm{X}$, in which these activities are described, is also missing from my primary manuscript, but can be found, for example, in the Bibliothèque Ste-Geneviève ms., cote 826, fols. 167-174.

54 Lezeau, La vie, fols. $40 \mathrm{v}^{\circ}$ and $42 \mathrm{v}^{\circ}$. She was in fact beatified much later (5 June 1791), but never canonized.

55 Ibid., fols. 54 and 137-138v ${ }^{\circ}$. For Anne de Saint-Barthélemy's complaints, see Bruno de Jésus-Marie, La belle Acarie, 377-80 ; and, Lezeau, La vie, fol. $137 \mathrm{v}^{\circ}$.

56 Following his will, Marillac's body was interred in the main Carmelite convent in Paris and his heart in the small convent. But the abbess of Saint-Anis Chantemesle had wanted the body in her convent near Châteaudun, as did the Recollets in the same town; the latter had to settle for a small portion of his entrails. Since an earlier version of his will had promised his heart to the Carmelites of Pontoise, they were sent "le surplus" and the larger share of his entrails (Lezeau, La vie, fols. 354-354v ${ }^{\circ}$ ).

57 For the friendship with Lezeau himself, see Lezeau, La vie, fols. 235-236v ${ }^{\circ}$.

58 In chapter XIV, “Comment il exerçoit la Justice," Lezeau reports Marillac as having a low opinion of many fellow maittres des requêtes and councillors. He seemed pleased to have an office somewhat in isolation above them, for he "had no interest in things of the world except in order to render account to God and the king" (fol. $214 \mathrm{v}^{\circ}$ ). This is not to be seen as either affirming or contradicting Lezeau's statement two pages later that Marillac "neither desired nor procured" his office (fol. $215 \mathrm{v}^{\circ}$ ). He felt that friends could be embarrassing to persons in high office, for it was easier to deny favors to those who could not make a claim on friendship. And he cited Saint Paul: "If I were still complaisant to men, I would no longer serve Jesus Christ" (fol. 214vo).
} 
time, avoided "confabulation or conversation" with his associates. ${ }^{59}$

Another large area of Lezeau's attention is Marillac's general disdain for things of this world - a disdain that he continually urged upon his children as well. Three early chapters, and a later one about his impending dismissal from office, describe in extensive detail and to an increasingly redundant extent, Marillac's lack of interest in wealth, country estates, and any but the most ascetic material possessions. ${ }^{60}$ Pressed by an insistent Queen Mother to accept a substantial gift, he told her that he would use it towards a marble tomb for Marie de l'Incarnation (the one still found in the chapel of the Pontoise carmel), and he put the Queen Mother's name and coat of arms on the tomb rather than his own. ${ }^{61}$

Nonetheless, he carved out for himself, from the recently acquired campus of the Carmelite mother house in Paris, a most commodiously and decoratively renovated hermitage/retreat, ${ }^{62}$ where he spent hours in devotional reading and meditation and which he asked the nuns to continue to lease to his widowed daughter-in-law, Marie de Creil, until her children had grown. It is true his financial and other contributions had helped make this convent, let alone the order, possible in the first place, and his daughter-in-law may have been relatively needy because of an inheritance squandered by the old man on religious philanthropy, but the fact is inescapable - a nobleman proud not to own a single country estate still possessed a pastoral retreat on the edge of town. ${ }^{63}$

Marillac did admit to the occasional need for modest display at official functions, but the impression left is that he avoided them as much as possible. ${ }^{64}$

59 Lezeau, La vie, fols. $241 \mathrm{v}^{\mathrm{o}}-242$. Not surprisingly, Saint Teresa makes the same comment in her autobiography: Soon after conquering one more of her many hurdles on the road to spiritual perfection, the Spanish saint writes, she was no longer able "to form a firm friendship, or to take any comfort in, or feel particular love for, any people except those whom I believe to love God and to be trying to serve him." The Life of Saint Teresa of Ávila by Herself, trans. J.M. Cohen (London: Penguin Books, 1957$), 172$.

60 Lezeau said that both when Marillac became a royal councillor in 1612 and when he became surintendant des finances in 1624, he took a vow never to use his office to enrich himself (fols. 46 $\mathrm{v}^{\circ}-47$ ). Five years before his death, Marillac sold his share of property inherited from his parents and expressed his relief at no longer owning "an inch of land" (fol. 65).

61 Lezeau, La vie, fols. $54 v^{\circ}-55$. In late 1629 he refused 100,000 livres that Richelieu tried to press upon him (fol. 62). On the grounds that she was burdened with debts, he stopped accepting the New Year's gifts (étrennes) he had received by virtue of being the queen mother's intendant de la maison after only two years in the office (fol. $62 \mathrm{v}^{\circ}$ ). He would not let the queen mother pay off a debt of 26,000 livres owed to a convent by his daughter (or daughter-in-law?) (fols. 63-64).

62 As enhancements to life at his hermitage, Marillac installed water facilities that tapped into the service from Rungis for the Palais du Luxembourg (the new Paris residence for the Queen Mother), acquired surrounding property for an expanded garden (to 2 arpents, 22 perches), and renovated the former prieur's residence. Paul et Marie-Louise Biver, Abbayes, monastères, couvents de femmes à Paris des origines à la fin du XVIII' siècle (Paris: Presses Universitaires de France, 1975), 273. Thus, Marillac's garden grew to about two and a fifth acres.

6.3 Before his death (even before his disgrace?), he sold his house at Fontainebleau, but as the royal court spent so much time there, it had been a possession necessary for his work. In Grillon, IV (1629), one finds a letter from Marillac to Richelieu dated 9 August, from Paris, "près Luxembourg" (\#499, p. 520); this is obviously written from his "hermitage."

${ }^{64}$ See Lezeau's reproduction of Marillac's long letter to "his daughter" (probably his daughter-inlaw, Marie de Creil), dated 27 July 1628 (fols. $47 \mathrm{v}^{\circ}-49 \mathrm{v}^{\circ}$ ), as well as fols. $80 \mathrm{v}^{\circ}-81 \mathrm{v}^{\circ}$. Lezeau says Marillac lodged apart from the court most of the time when travelling with it, and enjoyed passing the evening 
He is similarly depicted as avoiding honors, even deference to his person by virtue of his station. He said, "I cannot bear it that one man be the beatitude of another man." ${ }^{65}$ In a similar vein (though in fact respecting the day's conventions), he reprimanded his children for addressing servants familiarly instead of using the respectful "vous." 66

Lezeau presents him as having received his exalted offices in each instance without ever having sought them. But given Marillac's high opinion of his own capacities and his low opinion of many another person's rectitude or capacities, it seems likely that he made sure he was noticed whenever important royal appointments or tasks appeared. ${ }^{67}$ Noting how the ancient Greeks and Romans had striven so avidly for glory and honor, Lezeau feigns astonishment that, "even among us, several believe that [such ambition] does not much prejudice the evangelical law." He writes that Marillac avoided as much as possible basking in the renown of his own good and honest actions. ${ }^{68}$

Of related interest is the matter of charitableactivities. The Catholic Reformation extended its energies into the founding of hospitals, orphanages, and other forms of poor relief, and the Marian congregations described by Louis Chatellier spread as widely throughout France as they did anywhere else. ${ }^{69}$ Chatellier offers no hint that Michel de Marillac was involved in the work his study is about, but the earlier studies of Raoul Allier and Emanuel Chill lead us to a different picture. ${ }^{70}$ For one thing, Bérulle had been a pupil of the Jesuits (to whose schools Chatellier credits the formation of the Marian congregations) and remained almost an agent of theirs

with humble monks (fol. 139).

65 Lezeau, La vie, fol. $73 \mathrm{v}^{\circ}$. Marillac said that "...he knows very well how to conserve the dignity of his office, and that the humble spirit did not contradict the spirit of justice" (fol. $71 v^{\circ}$ ). See also fols. $68-74 \mathrm{v}^{\circ}$.

66 Ibid., fols. $143-143 \mathrm{v}^{\circ}$.

67 Georges Pagès states that Marillac "liked... to put himself to the fore" and that, "once become garde des sceaux, Marillac sought to supplant the surintendant d'Effiat in the king's favour." "Autour du "Grand Orage»; Richelieu et Marillac: Deux Politiques," Revue historique, vol. 179 (Jan.-June 1937): 65-66. (It is clear from several letters in Grillon, V [1630], that these two men worked together with great difficulty. After all, d'Effiat had replaced Marillac as surintendant, and Bonney judged the former's fiscal efforts more successful; interestingly, though, d'Effiat was also unusually honest. Bonney, King's Debts, 140-45.) Pagès also called Marillac "un personnage ambitieux": 66.

68 Lezeau, La vie, fols. 83 and $83 \mathrm{v}^{\circ}$. In a letter of 8 June 1623, Marillac wrote, "It seems that God gives me the consolations of this earth only in order to learn that they are nothing if they are not in him, by him and for him. Otherwise, they are a torment" (fol. 86). Marillac told Lezeau as many as fourteen years before his retirement that if he were ever reduced to living in a tower, he would know well how to fill his days in spiritual contemplation $\left(\right.$ fol. $\left.89 \mathrm{v}^{\circ}\right)$.

69 Louis Chatellier, The Europe of the Devout; The Catholic Reformation and the Formation of a New Society, trans. Jean Birrell (Cambridge/Paris: Cambridge University Press / Éditions de la Maison des Sciences de l'Homme, 1989; 1987), 172.

70 Respectively, Raoul Allier, La Compagnie du très Saint-Sacrement de l'autel: La "cabale des dévots" (Paris: Colin, 1902; Geneva: Skatkine Reprints, 1970), 59; and Emanuel Chill, "Religion and Mendicity in Seventeenth-Century France," International Review of Social History VII (1962): 421-22. It is from Chill that one learns the full title and the publisher of the 1902 edition of Allier's study; the Skatkine reprint offers only the sub-title and a set of dates: La cabale des dévots, 1627-1666. For the most detailed analysis of Bérulle's and Marillac's thoughts and activities on social issues, see Chill's dissertation, "The Company of the Holy Sacrament, 1630-1666," esp. cap. III (26-65), esp. 51-65. 


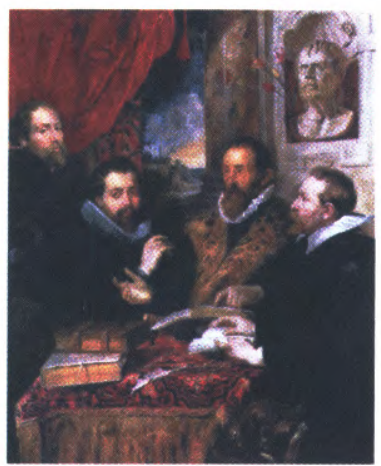

The Four Philosophers by Peter Paul Rubens, Oil on panel, c. 1611-1612.

Rubens depicts, from left to right, himself, his brother, Justus Lipsius and Jan Wowerius.

Palazzo Pitti, Galleria Palatina, Florence, Italy

until rivalry between his order and theirs developed in the $1620 \mathrm{~s}^{71}$ In 1629 , as already noted, Marillac and Bérulle were among those aspiring to found what became the Company of the Holy Sacrament, whose concerns were directed both at public order and care for eternal souls, and at the objective secular needs of the poor, and whose hospitals or other lodgings did provide some real relief. ${ }^{72}$ While Chatellier states that Bérulle's emphasis was on the inner life, not "activity in the world, good works or [even] participation in collective devotions," ${ }^{\prime 73}$ the Company actively became involved in poor relief, more so after Richelieu's triumph over the dévots terminated the political aspects of their religious energies and turned them to purely social outlets.

Thus, it is perhaps surprising to find so little in Lezeau connecting Marillac with any of the social issues of his day. There are, of course, the predictable hagiographical stories about money given to beggars. ${ }^{74}$ He strove to discern individual merit in those who sought his help; such persons received references or money, and Lezeau's implication is that some of those so assisted had originally been strangers to Marillac.

All Lezeau's descriptions of Marillac's attitude and stories of his behavior are dressed in religious terms and often appear intended to argue a hagiographic brief, literally to assist or initiate the process of canonization. On the other hand, the later Renaissance period witnessed a significant revival of Stoic philosophy. Just as ancient Stoicism contributed to the growth and spread of Christianity, so, in early

\footnotetext{
71 Chill, "Company," 60, 63.

72 Ibid., 406, 418, 421.

73 Chatellier, Europe of the Devout, 155. But see Chill: "Common devotions were stressed..." ("Company," 61; my emphasis); and, concerning the outward orientation of religious devotion, Diefendorf: for the members of Acarie's circle, "even the highest state of mystical absorption into God was not envisioned as an end in itself but as a means of activating oneself to serve as God's tool or agent" (Diefendorf, From Penitence, 90).

${ }_{74}$ See Lezeau, La vie, fols. $56-57 \mathrm{v}^{\circ}$, for a striking letter condemning beggars on what we would now call classical liberal grounds. See also fols. 58 and 116.
} 
modern France and elsewhere, it reinforced the Catholic Reformation, especially in legal and humanist circles. In fact, Gerhard Oestreich sees in "constitutional changes in the state, political and spiritual repression, [and] legal insecurity" three social conditions that during the Counter Reformation replicated those of the early Roman Empire. "Around 1600," he writes later, "especially in the France of Henry IV and the Netherlands, Stoicism became the ideology, almost the religion, of educated men." ${ }^{75}$

It would be difficult to disentangle the religious from the philosophical components of anyone's virtue, but were we to lack other evidence for Marillac's piety, we could ascribe a good deal of his ascetic life style, high morality, and general rectitude to an almost secular side of his age's educated culture. In Lezeau's biography, there is little direct evidence that Marillac demonstrated Stoic influences on himself. But the ancient Stoic Seneca is cited at least once, in connection with an attack on the evils of secular ambition. ${ }^{76}$ And Lezeau quotes from one of Montaigne's essays after having said that Marillac did not care who received the glory for the things he did: "Everything else is subject to barter: we will let our friends have our goods and our lives if needs be: but a case of sharing our fame and making someone else the gift of our reputation is hardly to be found."77 Furthermore, in the entourage of Marie de Médicis, the influence of the Dutch Stoic Justus Lipsius can be traced through at least two routes. One is through her famous painter, Peter Paul Rubens, who painted Lipsius several times and whose brother, Philip (d. 1611), had been one of Lipsius's pupils and boarders. ${ }^{78}$ The other

75 Gerhard Oestreich, Neostoicism and the early modern state [sic], eds. Brigitta Oestreich and H.G. Koenigsberger, trans. David McLintock (Cambridge: Cambridge University Press, 1982), 15, 37. Also see Jason Lewis Saunders, Justus Lipsius: The Philosophy of Renaissance Stoicism (New York: The Liberal Arts Press, 1955).

76 Because of Marillac's scrupulous integrity in deciding whether or not to grant favors to courtiers and royal officials, he was the subject of calumny around the king. "Cette peine est des plus grandes, de servir avec le degoust de son maistre, à un homme de bien qui aymeroit mieux la retraitte avec Dieu qui ne peut donner de contentement la pourpre, l'applaudissement et la puissance qui sont, dit Seneque, les trois poincts où l'ambition tend." Lezeau, La vie, fol. 171.

See Grillon, e.g., V (1630), \#31 (from Paris, 22 January), in the postscript, 43-44; and \#92 (S.1., 23 February), 54, this being especially interesting, as one of the many references to Paul Hay du Chastelet as a principal fomenter of rumors against Marillac. In the polemics of the early 1630s, Hay du Chastelet took the lead against the disgraced dévots and even edited the anthology of pamphlets, Recueil de diverses pièces pour servir à l'histoire in 1635, to which Matthieu de Morgues responded with his own recueil in 1637. See especially my dissertation, Writers against the Cardinal: A Study of the Pamphlets which Attacked the Person and Policies of Cardinal Richelieu during the Decade 1630-1640 (Ph.D. dissertation, University of Minnesota, 1973), 2 vol.; but also William Church's magisterial Richelieu and Reason of State (Princeton: Princeton University Press, 1972). See, further, in Grillon, V (1630), \#155 (from Troyes, 31 March), where Marillac supplicates Richelieu to rest assured of "his very humble service, ...all my life" and hopes that the calumnies will always break up "against the rock of your protection," 166.

77 Lezeau, La vie, fol. 71. The quotation comes from the Essais, Livre I, Châpitre 41, "De ne communiquer sa gloire." I have used M.A. Screech's translation. Michel de Montaigne, The Complete Essays (Harmondsworth, Middlesex: Penguin Books, 1993), 285-86. On Neostoic influences on Montaigne, see for instance M.A. Screech, Montaigne and Melancholy: The Wisdom of the Essays (London: Duckworth, 1983).

78 Oestreich, Neostoicism, 95. If in doubt about a liaison between Rubens and Marie, recall the great series of twelve signal moments in the life of Marie de Médicis painted by Rubens (which virtually 
is through Pierre Jeannin (1540-1622), an ex-Leaguer, member of the Parlement de Dijon, and from 1616 to 1619 surintendant des finances, who said of Lipsius's Politics "that there was nothing in them that was not borne out by experience."79

If something of Marillac's approach to personal austerity and political strictness could be assigned merely to the pious-humanist Neostoicism of his day, much of it goes well beyond that. To see this we must turn to the strict elements of his piety and religious practices. It is not surprising to read (even if not otherwise verifiable) that thrice, between the ages of ten and twenty-two, Marillac had a strong desire to enter the church but that he was always dissuaded by family or teachers. ${ }^{80}$ Nor are we surprised by tales of his self-sacrifice in a youthful neardrowning incident, or his rejection of the advances of a loose woman ${ }^{81}$ Lezeau also mentions Marillac's "oraison mentale" at 1:00 in the morning, showing that he engaged in the same private "methodical prayers" as did many other dévots. ${ }^{82}$

Marillac's later interest in the Carmelites has an almost formulaic beginning. His fortuitous discovery and purchase of St. Teresa's autobiography in a Paris bookshop at the end of the summer in 1601, his initial resistance to the impact it had on him, where and when he read this passage or that, and the manner of his entering into a deeper acquaintance with Mme. Acarie (whose husband, Lezeau fails to mention, studied at the Collège de Navarre just a year or two ahead of Marillac), all have a providential ring to them..$^{83}$ Although few members of Mme. Acarie's elitist circle had much familiarity with poverty, they did at least possess the concerns driven by conventional Christian faith. ${ }^{84}$ In From Penitence to Charity, Barbara Diefendorf traces the gradual evolution of religious commitment and

have a room to themselves in the Louvre Museum). Rubens also created the original design for the frontispice of de Morgues's 1637 anthology (recueil) defending the Queen Mother (cf. note 76). Even more famous as a Stoic than Pierre Jeannin (see next note) was Guillaume du Vair (1556-1621), whom Marie's regency appointed garde des sceaux in 1616 and bishop of Lisieux in 1617. Du Vair had written three well regarded books on Stoicism between 1582 and 1594.

79 Quoted in Oestreich, Neostoicism, 107. Charles Perrault (1628-1703) writes that when orders arrived in Dijon to extend the St. Bartholomew's Day massacres (August-September 1572) to that city, Jeannin refused, saying he did not believe that orders for such cruelty could come from the king (Les Hommes illustres qui ont paru en France pendant ce siècle [Paris: A. Dezaillier, 1696-1700], vol. I, 74-75). This refusal could be interpreted as reflecting Neostoic ideals; as indicative of personal philosophy, it hardly matters whether the anecdote is true or not.

${ }^{80}$ Lezeau, La vie, fols. $119 \mathrm{v}^{\circ}-120 \mathrm{v}^{\circ}$ and $122-122 \mathrm{v}^{\circ}$. On one of these occasions, he had wanted to join the Carthusians.

${ }^{81} \quad$ Ibid., fols. $122 \mathrm{v}^{\circ}$ and $123-123 \mathrm{v}^{\circ}$, respectively.

82 Ibid., fol. $125 \mathrm{v}^{\circ}$. Speaking of "the piety, the religious fervor of the French between 1590 and 1620," Febvre writes that its "central character... was the practice of oraison méthodique, which had long been the privilege of [priests, monks and nuns]." In "Aspects méconnus d'un renouveau religieux," Annales, 641.

${ }^{83}$ Lezeau, La vie, fols. $23 \mathrm{v}^{\circ}-24$ and 25. For Marillac and Acarie at the Collège de Navarre, see J.-B.-A. Boucher, Histoire de la bienheureuse Marie de l'Incarnation dite dans le monde madame Acarie, nouv. édit. (Paris: Jacques Lecoffre, 1854), I, 214.

${ }_{84}$ It should be noted that Barbe Acarie had threatened to denounce her own mother as a grain hoarder in 1590 if she would not share with the poor. Mme. Acarie, in fact, revived among women of her social status the practice of visiting hospitals for the poor, herself frequenting both the Hôtel-Dieu and the Hôpital de Saint-Gervais (Cadoudal, Madame Acarie, 68-69). 
action in the Parisian Catholic Reformation, from austere penitential practices to socially oriented work amongst the poor. But she also shows that, while spiritual objectives remained important to the more charitably oriented later generation, visits and service to the poor and sick were among the works of the earlier generation.

Diefendorf's work demonstrates the devout piety of laywomen, whether single, married, or widowed, only some of whom entered religious life. Although Marillac's spiritual practices and religious service paralleled those of Diefendorf's laywomen, his were less representative of laymen. Among the names scholars regularly list as part of Acarie's pious circle, Marillac's is that of one of only two males who were not some sort of cleric.

Marillac also enjoyed religious visions, for the recounting of which we are not uniquely dependent on Lezeau. One of these also displays his extraordinary capacity for strict reasoning and self-restraint. During a visit with the now Marie de l'Incarnation, her complexion abruptly changed and she told him that the Virgin and Child had just appeared to her behind his head. Marillac quickly suppressed his initial urge to turn around to see the vision for himself, upon thinking that if Mary and Jesus had intended for him to see them on this occasion, they would have so positioned themselves. ${ }^{85}$ After his spiritual friend's death, Lezeau claimed, Marillac experienced her presence, through an especially beautiful scent, when he was at worship alone. ${ }^{86}$

Marillac told selected friends he had been visited by Mary and Jesus on more than one occasion, most often in moments of human weakness or when he was faced with a difficult decision in some affair of consequence. ${ }^{87}$ The visits from his guardian angel particularly increased after his disgrace. ${ }^{88}$ And some time before his death, he received a vision of God the Father Himself, come to take Marillac to the highest parlement of all. While expressing how deeply he appreciated this special grace, Marillac persuaded his divine visitor that he had work yet to do on earth. Not at all offended, God later returned again in person to Marillac, this time to be received compliantly, by a man now racked with pain and anxiously awaiting his end. ${ }^{89}$

The last third of the manuscript is virtually an eight-chapter passion play,

\footnotetext{
${ }_{85}$ Lezeau, La vie, fol. 39. A painting of this event hangs prominently in the parlor of the convent at Pontoise: La Vierge à l'Enfant apparaissant à la bienheureuse soeur Marie de l'Incarnation, attributed to Pierre Delestres (French School), mid-seventeenth century. It is reproduced in two exposition catalogues of Carmelite art (of 1982, under the direction of Gilles Chazel, and of 2004, under that of Christian Olivereau, respectively), but perhaps most accessibly in Jean-Dominique Mellot, Histoire du Carmel de Pontoise, I, 1605-1792 (Paris: Desclée de Brouwer, 1994), 38, where it is entitled "Michel de Marillac et soeur Marie de l'Incarnation au parloir (Pontoise, avril 1618)." All three of these reproductions are in color. In B\&W, this picture may also be found as Figure 4 (p. 455) in my edition of Lezeau's Vie de Marillac.

86 Lezeau, La vie, fols. $40-40 \mathrm{v}^{\circ}$.

${ }^{87}$ These are divine favors that he reported, respectively, to the bienheureuse Marie Magdeleine de Saint-Joseph, Carmelite, and to his chaplain, le sieur Holden. Ibid., fols. $343 v^{\circ}-344$ and $344 v^{\circ}$ and 346.

${ }^{88}$ Ibid., fols. $347 \mathrm{v}^{\circ}-348 \mathrm{v}^{\circ}$.

89 lbid., fols. $349-349 \mathrm{v}^{\circ}$.
} 
beginning with a demonstration of how frequently Marillac tried to resign the seals. For those who knew the issues at stake in the royal council, the account is replete with nuances of the political rift between Richelieu and Marillac. Yet nothing is explicitly said to inform the reader of the issues involved.

To overcome the Huguenot capacity to initiate disturbances within France, the two men had worked together, first, at La Rochelle (1627-28), and immediately thereafter, in Languedoc. In a letter urging Richelieu to follow up the military victory by filling "all these provinces with missionaries, Recollets, Capuchins, Fathers of the Doctrine, Oratorians, Jesuits and others," Marillac wrote that such work was "the end and goal of the designs of God, for which He has worked those wonders of which you have been the most worthy instrument...."90 But the rift had already started.

In mid-February 1630, after the temporary lifting of the siege of Casale in Italy, Marillac wrote that, in spite of "the confidence I have that God guides you," he thought consolidation of the victories in Languedoc was more important thān any gains that might be made in Italy. He thought the army in Italy was pressing farther than was necessary: "one is becoming engaged without at all seeing the consequences clearly or assuredly"; enemies at home and abroad would take advantage of France's distractions; and he did not know "if we have the blessing of God for such projects." ${ }^{\prime 1}$

This brief recounting of the issues that came to divide the two colleagues (to which Marillac's concerns about increasingly widespread poverty must also be added ${ }^{92}$ ) reinforces the point that Marillac's religiosity informed his political judgements. But the rupture between the two is denied explicit expression, as Lezeau presents Marillac's urge to resign in terms of an elderly man's religious desire to be freed of worldly cares. ${ }^{93}$ When the seals are at last seized from Marillac,

90 The letter was written from Paris on 16 August 1629 (Archives des Affaires Etrangères, Mém. et doc., France, t. 794, fol. 97), published as \#521 in Grillon, IV (1629), 543-45 (our passage on 544). It is cited in Pagès, "Richelieu et Marillac," 73.

${ }^{91}$ “...On s'engage sans voir bien clair ou bien assurement l'yssue, ...et que je ne scay pas si nous avons bénédiction de Dieu pour ces desseins là..." (Arch. Aff. Etr., Mém. et doc., France, t. 793, fol. 72, cited in Pagès, "Richelieu et Marillac," 77). I cannot find this letter in Grillon, $V$ (1630), but see \#410 (Grenoble, 17 July 1630, after the siege is resumed), 406; \#426 and \#434 (both Grenoble, 22 and 24 July), 419 and 427-31; and Richelieu's responses in \#485 (S.1., 6 August, with its rather sarcastic last paragraph), 491-92.

92 See, for example, Grillon $V$ (1630), \# 224 (Dijon, 6 April), 234, last paragraph.

93 The letters in Grillon's Tome $V$ do not provide evidence to support Lezeau's claim that Marillac continually tried to resign from office, but they do not explicitly support the opposite view either. What they show is that Marillac frequently complained of ill-health and ailments that prevented or retarded the travel and work Richelieu asked him to undertake as king and cardinal proceeded with their invasion of Italy. Marillac apologizes for the delays, but in every instance he reaffirms his desire to serve these two masters, and his loyalty to their goals (even as he also regrets the neglect the invasion imposes on addressing urgent matters in Languedoc and elsewhere). There is absolutely no mention of wanting to be relieved of his duties. Grillon, $V$ (1630), for example \#336 (Lyons, 25 June), \#340; and \#350, 351 and 358 (all from Grenoble, 30 June, 30 June and 1 July), 352, 352-53, 357: Marillac gets tired after two leagues, he's in a littière, he's grateful for the mules Richelieu sent to carry him, etc.: "Néantmoins, Monseigneur, disposez, disposez [sic], s'il vous plaist, de $\mathrm{v}^{\mathrm{re}}$ serviteur librement" (357). Related to this 


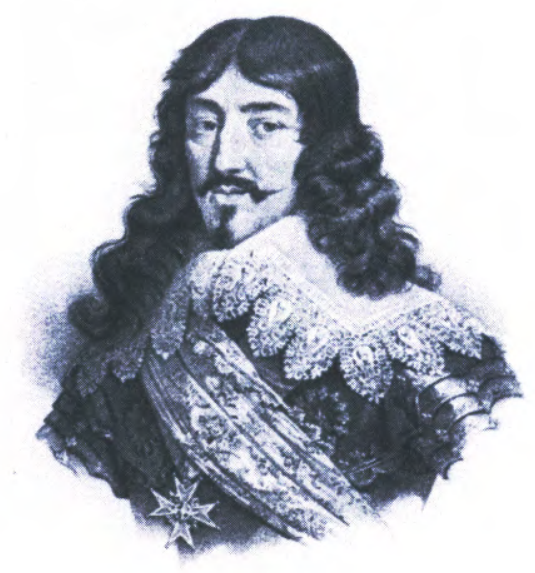

Louis XIII.

Image Collection of the Vincentian Studies Institute

abruptly and rudely, and he is placed under tight military guard and forced to travel, the injustice of the event is played up indirectly, while the professions of Marillac's loyalty to Louis XIII, and even to Richelieu, are given emphasis. Marillac is shown as courteous, even generous, towards his guards and as exhorting his friends to forgive them, for they served the king and knew not what they did.

The rigors of forced travel, incommodious eating and sleeping arrangements, separation from most of his servants and friends, lack of privacy, and rude treatment from the guards aggravated Marillac's now fragile health and hastened his end. ${ }^{94}$ Lezeau narrates his last days one at a time. We learn of every meal, visit, purging of blood, page written or read, each reception of the sacrament, adjustment of the chair or pillow, neglect of food, and consultation with priests and doctors - both those in his service and those brought in from the neighboring village. The picture is one of an elderly man suffering deeply from accumulated physical ailments and personal grievances, who bears all with Christian (and Stoic?) resignation, being generous to all, devoted to his attentive daughter-in-law and his grandchildren, loyal to His Majesty the King, and continuously focused on God and salvation.

Both in the narrative chapters and in a sequel, entitled "Des graces speciales qu'il a receues de Dieu" (XXIII), Lezeau describes Marillac as accepting everything according to God's providence. Whether it is the call his grand-daughters received to enter the religious life, or the premature death in 1621 of his eldest son so successfully tracing his father's career in the royal service, Marillac ascribes the incident to divine favor. After learning of René's death and before informing his

issue of wanting to resign, Marillac frequently refers to rumors of a rift between Richelieu and himself, and goes to every length to reassure Richelieu that they are unfounded. For example, Grillon, IV (1629), \#506 (Paris, 11 August), 527-28, and similar letters cited earlier.

${ }_{94}$ Lezeau had stated earlier that a considerable number of physical ailments beset Marillac right after his assuming high office in 1624, and that they left him, in fact, soon after his arrest (La vie, fol. 153-54). 
daughter-in-law of her loss, he took her to the convent of the Carmelites in Paris and had them both receive communion. ${ }^{95}$

This is a man whose almost every act was informed with a religious consideration or spiritual dimension - certainly above the beliefs and practices of most laymen (and even most clergy), especially above those in elevated positions of wealth and power. While he was, I think, prudish and vain, ${ }^{96}$ he did not otherwise resemble Molière's Tartuffe. He was loudly firm and candid in his dealings with those around him, but did not seek public recognition for his many services to religious orders. ${ }^{97}$ Still, displays of arrogance betrayed his frequent expressions of modesty. Georges Pagès states, "He was of a very authoritarian temperament: all contemporaries affirmed it." Marillac was "strongly attached to his opinions, because he felt that they conformed to the call of his conscience and of his faith...." ${ }^{98}$ In sum, Michel de Marillac was pious and spiritual to an extent noticeably beyond the normal even in a deeply religious century. Despite possible criticisms of many of his personal traits, we should not doubt his sincerity and commitment; we should willingly accord him spiritual experiences not shared by most practicing Christians.

Lezeau's manuscript reveals the seventeenth-century religious mentalité through the representation of one of its extraordinary practitioners. Although little was ascribed to Marillac that is not amply found in the lives of the century's outstandingly dedicated religious figures, as a layman so centrally placed in the corridors of secular power, he was unusual in his searching for and experiencing such a spiritually enriched life. In short, he came very close to embodying the aspirations that François de Sales and Nicolas Caussin held out for pious laymen and women. And through his biography, Lezeau exemplifies the attitudes, practices and aspirations of the Catholic Renaissance in France. But the point of seeking to grasp his convictions and practices is not merely to see in Marillac an extraordinary Christian, but to see how, in him, power and piety were inseparable. The contributions Marillac made to the monarchy of Louis XIII, and the growth of French absolutism, can only be fully understood in the context of this particular statesman's religiosity.

\footnotetext{
$95 \quad$ Ibid., fols. $164 \mathrm{v}^{\mathrm{o}}-165 \mathrm{v}^{\mathrm{o}}$.

96 Lezeau writes that Marillac felt a man of honor and quality should abstain from "railleries et bouffoneries" merely for the sake of making his companions laugh (fol. 125).

97 Lezeau states that Marillac asked the biographer of Marie de l'Incarnation (Mme. Acarie), André Du Val, not to mention that he was among those who received the special vision and three commandments that led to his collaboration in the establishment of the Carmelites in France (fol. 25).

98 "Il était de tempérament très autoritaire: tous les contemporaines l'affirment." “Autour du « Grand Orage "," 65, 66 .
} 